\title{
フェニルグリシジルエーテルとドデシル メルカプタンとの反応
}

\section{根 来 健 二*・大 塚 敏 秀*}

Reaction between Phenyl Glycidyl Ether and Dodecyl Mercaptan.

Kjeni NEgoro* and Toshihide OHzuKA*

\begin{abstract}
In order to elucidate the curing reactions of epoxy resins, the reactions between phenyl glycidyl ether and dodecyl mercaptan were investigated. Thus, changes in the number of free epoxy-and mercapto-groups as well as in viscosities were quantitatively determined over a duration of time. The results indicated that the reaction was accelerated by the addition of an amine such as triethylamine and tri- $n$-butylamine. Ethyl alcohol and metallic sodium, etc. also served as effective catalysts. Addition reaction of dodecyl mercaptan to phenyl glycidyl ether occurred at temperaturesand above $40^{\circ} \mathrm{C}$ in the presence of a catalyst such as triethylamine. above $150^{\circ} \mathrm{C}$ without catalysts. jn the presence of triethylamine phenyl glycidyl ethev reacted more readily with lauryl alcohol than dodecyl mercaptan.
\end{abstract}

\section{I. 緒言}

エポキシ樹脂の硬化剤としてアミン類，有機酸および 酸無水物など，低分子量活性水素化合物が普通使用され ている。また，一方エポキシ樹脂を硬化させると同時に 樹脂の物性を改良するためにフェノール樹脂, ポリアミ ド樹脂，ポリサルファイド1のように 2 個以上の活性水 素を有する高分子物質による変性も行なわれている。エ ポキシ樹脂硬化反念機構はモデルとしてフェニルグリシ ジルエーテル (以下 PGE と略記) と, アミン, 酸無水 物, フェノールおよびアルコールとの反応の研究により 推察されている2 6)。また同様に，エポキシ樹脂を液状 多硫化重合物で変性すると”), エポキシ樹脂は柔軟性を 帯び, 耐衝撃性, 耐摩耗性, 曲げ強度および切断破壊強 度が向上する。さらに配合上エポキシ樹脂/液状多硫化

* 広島大学工学部応用化学科 (広島市千田町 3 丁目)

* Department of Applied Chemistry, Faculity of Engineering, Hiroshima University. (Sendamachi 3, Hiroshima-shi, Japan)
重合物の混合比，使用するエポキシ樹脂および硬化肪の アミンの種類などにより，広範囲の諸性質を有しえる。 ここに用いた液状多硫化重合物は分子の両端にメルカプ 卜基を有する分子量 500 4000のものである。以上の ことからメルカプタンとエポキシドの反応機構を知るこ とは, 硬化反忘に対する知見をえる上に重要であると思 われる。しかし，メルカプタンとエポキシドの反応につ いては, 硫化水素とエポキシドの反応速度の研究 ${ }^{\text {s. }}$ が報 告されているのみである。そこでメルカプタンとしては 高沸点物の必要性からドデシルメルカプタン（以下 DM と略記）を用い，エポキシドとしては PGE き用いて， 硬化反応と結びっけるために無溶媒で 3 級アミンを触媒 として実験を行なった。

\section{II. 実験方法}

\section{1. 原料調製}

i. PGE 文献》にしたがって合成して, 減圧蒸留で bp $137 \sim 145^{\circ} \mathrm{C} / 31 \mathrm{mmHg}$ の留分（理論収率 $50 \%$ ）に粉 末水酸化ナトリウム $1 \mathrm{~g}$ を加え, 水浴上で 3 時間加温し 
て，残存塩素分を除いたのち，初，後留をそれぞれ $20 \%$ づつ除いて bp $89^{\circ} \mathrm{C} / 2 \mathrm{mmHg}$ で 2 回真空蒸留した。ジ オキサンー塩酸法 ${ }^{32}$ により求めた純度は $99.5 \pm 0.2 \%$ で あった。

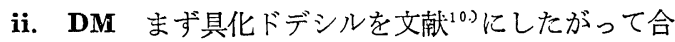
成し， 2 回減圧蒸留を行ない精製した。bp $108 \sim 109^{\circ} \mathrm{C} /$ $2 \mathrm{mmHg}$, 収率 $60 \%$ 。ついで DM は文献 ${ }^{11}$ にしたがっ て合成した。3 回減圧蒸留を行ない bp $147^{\circ} \mathrm{C} / 11.5 \mathrm{~mm}$ $\mathrm{Hg}$ (臭化物に対し収量 $60 \%$ )，156 ${ }^{\circ} \mathrm{C} / 20 \mathrm{mmHg}, 108^{\circ} \mathrm{C} /$ $2 \mathrm{mmHg}$ の物をえた。メルカプト基の定量法 ${ }^{12}$ による純 度 $98.9 \pm 0.4 \%$ 。

iii. その他の試薬 ラウリルアルコール，ジメチル アニリン，キノリン，ピリジン，トリ-n-ブチルアミン， トリエチルアミンは試薬特級品を 1 回真空蒸留して用い た。 $p, p^{\prime}$-テトラメチルジアミノジフェニルメタンはア セトンで再結晶, $\mathrm{mp} 87 \sim 88^{\circ} \mathrm{C}$ のものを用いた。他に， 純エタノールは 99\% エタノールを金属ナトリウムで脱 水後蒸留したもの，ジラウリルスルフィドは $\mathrm{mp} 37 \sim$ $38^{\circ} \mathrm{C}$ のものを用いた。

2. 実駼方法 恒温槽で反応温度に調整した PGE を $3 \mathrm{~m} l(3.2 \mathrm{~g}), \mathrm{DM}$ を $5 \mathrm{~m} l(4.1 \mathrm{~g})$ (PGE : $\mathrm{DM}=1$. $05: 1$ モル比) づつピペットでそれぞれぬき出し，反応 管（直径 $2.4 \mathrm{~cm}$ ，高さ $20 \mathrm{~cm}$ ）に入れ混合したのち，た だちにエポキシ基に対して所定モル比の触媒を添加し， 反応進行中の各時間に分析試料を $1 \mathrm{~m} l$ のメスピペット でとり出し，エポキシ基とメルカプト基の反応量を求め た。すなわち，エポキシ基の定量は文献にしたがい(2)， エポキシ量 $(\mathrm{m} \mathrm{M} / \mathrm{g})$ を求め，かつブランクテストを行 なって補正した。またメルカプト基の定量 ${ }^{12)}$ は同じくブ ランクテストを加え，メルカプト基量 $(m \mathrm{M} / \mathrm{g})$ を求め た。な抢，反応率は分析精度の関係から PGE の価を用 いて，つぎの式を用いて計算した。

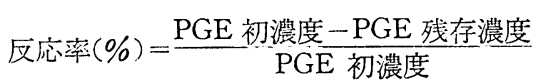

\section{III. 実験結果ならびに考察}

1. 無触媒反応の温度による影暗 無解媒で PGE と $\mathrm{DM}$ とは低温ではほとんど反応せず， $150^{\circ} \mathrm{C}$ 以上を 要する。この結果を図 1 亿示す。

その際，図 1 の実線で結ばれた曲線は PGE の減少か ら求めた反応率曲線で，点線で結ばれた曲線はメルカプ タンの減少から求めた反応率曲線である。反応はいずれ も温度の増加とともに著しく增している。また PGE と DM との反応を考えてみると

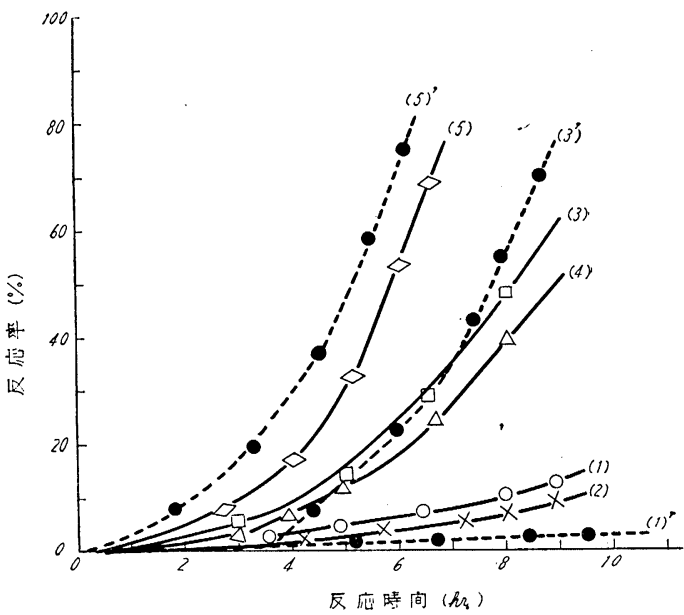

図 1 無触媒反応の温度による影響

$\begin{array}{lcc} & \text { PGE : DM } の \text { M比 } & \text { 反応温度 } \\ \text { (1) } \bigcirc & 1: 1 & 150 \pm 0.2^{\circ} \mathrm{C} \\ (2) \times & 2: 1 & " \\ \text { (3) } \square & 1: 1 & 180 \pm 0.2^{\circ} \mathrm{C} \\ \text { (4) } \triangle & 2: 1 & " \prime \\ (5) \diamond & 1: 1 & 190 \pm 0.2^{\circ} \mathrm{C} \\ (1)^{\prime} & 1: 1 & 150 \pm 0.2^{\circ} \mathrm{C} \\ (3)^{\prime} & 1: 1 & 180 \pm 0.2^{\circ} \mathrm{C} \\ (5)^{\prime} & 1: 1 & 190 \pm 0.2^{\circ} \mathrm{C}\end{array}$

1)

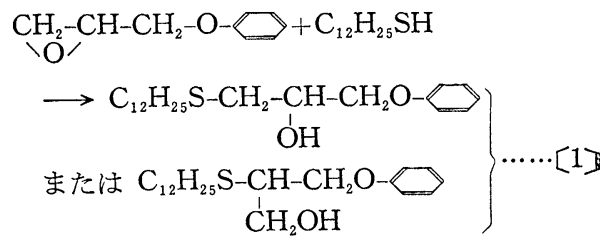

2)

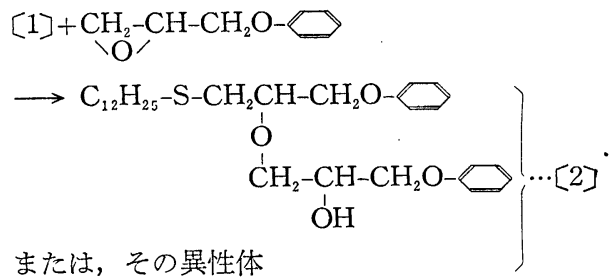

図 1 の無解媒下における PGE と DM との減少速度 を比較すると, $150^{\circ} \mathrm{C}$ では PGE の方が大きく（図 1 の $\left.1,1^{\prime}\right), 180^{\circ} \mathrm{C}$ ではほぼ等しく $\left(3,3^{\prime}\right), 190^{\circ} \mathrm{C}$ では $\mathrm{DM}$ の方が大である $\left(5,5^{\prime}\right)$ 結果となった。〔1〕反応が主とし て起ると PGE とDM との減少割合は相等しく,[2]の 反応を伴う場合には，エポキシ基の減少割合が大となる から， $180^{\circ} \mathrm{C}$ では〔1〕反応が主として起り, $150^{\circ} \mathrm{C}$ では 〔2〕の反応も起っていると推察される。また $190^{\circ} \mathrm{C}$ では DM の減少速度が大であるのは, 多分酸化分解など（た とえば $\mathrm{C}_{12} \mathrm{H}_{25} \mathrm{~S}-\mathrm{S}-\mathrm{C}_{12} \mathrm{H}_{25}$ の生成 $\left.{ }^{13)}\right)$ が起るためであろ 亏。

2. ジメチルアニリン添加の影響 結果を 図 2 に 


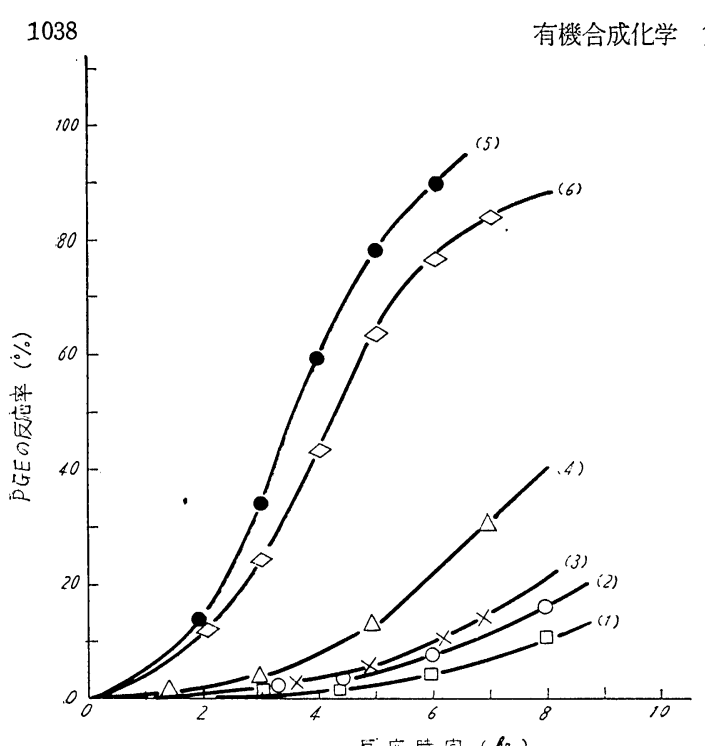

图 2 ジメチルアニリン添加量の影絽 PGE : DM : シメチルアニリンM比, 反応温度 (1) $\square$ 無触媒反応

(2) $\bigcirc \quad 1: 1: 0.031(0.08 \mathrm{~g}) \quad 150 \pm 0.2^{\circ} \mathrm{C}$

(3) $\times \quad 1: 1: 0.067(0.17 \mathrm{~g})$ "

(4) $\triangle \quad 1: 1: 0.143(0.36 \mathrm{~g})$ "

(5) $1: 1: 0.143(0.36 \mathrm{~g}) \quad 180 \pm 02{ }^{\circ} \mathrm{C}$

(6) $\diamond \quad 1: 1: 0.124(0.67 \mathrm{~g}) \quad 150 \pm 0.2^{\circ} \mathrm{C}$

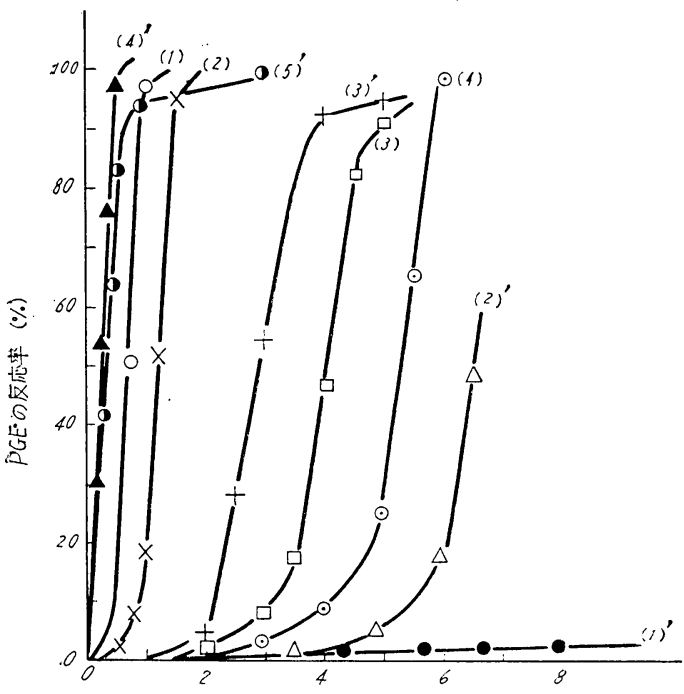

反度時间 ( $\mathrm{Ar}$.

图 3 トリエチルアミン添加量の影整ならびにトリーn一 ブチルフミン添加下の反応温度による影留 アミン添加監の影響 $\left(50 \pm 0.1^{\circ} \mathrm{C}\right)$ $\mathrm{PGE}: \mathrm{DM}:$ : アンM 比

(1) $\bigcirc 1: 1$ : トリエチルアミン $0.1(0.22 \mathrm{~g})$

(2) $\times 1$ : 1 : トリエチルアミン $0.05(0.11 \mathrm{~g})$

(3) $\square \quad 1$ : 1 : ピリジン $0.01(0.02 \mathrm{~g})$

(4) $\bigcirc \quad 1: 1$ : ピリシン $0.15(0.25 \mathrm{~g})$ トリーnープチルアミン触媒反応の滥度:よっ影猆 PGE : DM : トリ $-n$ ブチルアミン =1:1:0.1M
$\begin{array}{ll}(1)^{\prime}-30 \pm 0.1^{\circ} \mathrm{C} \\ (2)^{\prime} \triangle & 40 \pm 0.1^{\circ} \mathrm{C}\end{array}$
トリーnープチルアミン $0.39 \mathrm{~g}$ 添加)
(3) $+50 \pm 0.1^{\circ} \mathrm{C}$
$(4)^{\prime}$ \& $100 \pm 0.1^{\circ} \mathrm{C}$
$(5)^{\prime}\left(\begin{array}{l}100 \pm 0.1 \mathrm{C} \\ 150 \pm 0.1^{\circ} \mathrm{C}\end{array}\right.$

(100)

示した。図 2 からジメチルアニリンの添加量の增大と之 もにわずかであるが触媒効果が認められた。また（4)， （5）から温度の上昇もかなり触媒効果を大とする結果を えた。

3. トリエチルアミンおよびトリ-n-ブチルアミン 添 加の影響 結果を図 3 に示した。

トリエチルアミンおよびトリーnーブチルアミンの触媒 効果は非常に大である。添加量をふやす上急速に反応完 結に導く。トリーnーブチルアミン触媒の温度による影響 は大で， $30^{\circ} \mathrm{C}$ ではほとんど反応しないが， $50^{\circ} \mathrm{C}$ 以上で は早くなり，また誘導期間も著しく減少する。 $50^{\circ} \mathrm{C}$ に おける塩基の触媒能を比較するとトリエチルアミンが最 大で，ついでトリ-n-ブチルアミン，ついでピリジンの 順になった。

4. 各種塩基の影響 つぎに, 各種塩基類の $150^{\circ} \mathrm{C}$ における触媒効果の大小を 図 4 と示した。

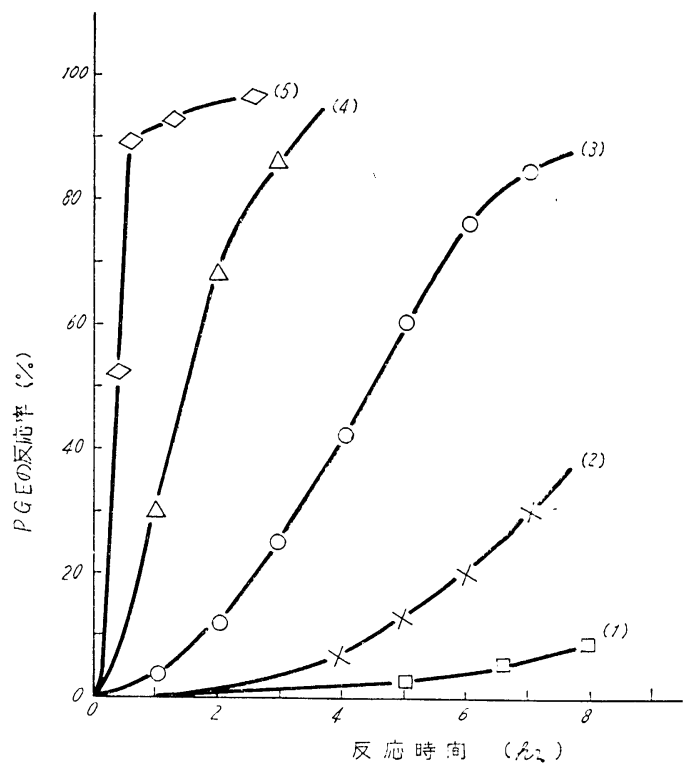

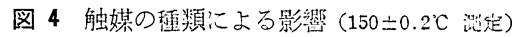
$\mathrm{PGE}: \mathrm{DM}:$ アミンM比
(1) $\square 1: 1: 0$ (無触媒)
(2) $\times 1: 1: \ddot{シ ゙ メ ル ア ニ リ ン ~} 0.143(0.36$ g)
(3) $\bigcirc 1: 1: p, p-1$ テトラメチルジアアシシフェ ニルメタン $0.124(0.67 \mathrm{~g})$
(4) $\triangle 1: 1:$ : $1:$ リン $0.23(0.63 \mathrm{~g})$
(5) $\diamond 1: 1:$ : 1 -n-ブチルアミン $0.1(0.39 \mathrm{~g})$

図 4 から， $150^{\circ} \mathrm{C}$ にお汀る解媒能を実施条件で比較する と，トリ-n-ブチルアミンが最大で，ついでキノリン， $p, p^{\prime}-$ テトラメチルジアミノジフェルメタン, ジメチル アニリンの順であった。

つぎに，PGE-DM-トリエチルアミン混台系に第 2 の 添加物を加えた場合の反応を銅べたとこう, 図 5 (1), 
(2), (3), (4) のごとき結果をえた。また PGE-DM 混合 系に金属ナトリウムを添加したときの結果を図 5 (1)', (2)' に示し，さらに(2)' の上にエチルアルコールを加 えたときの結果を図 $5(3)^{\prime}$ に示した。

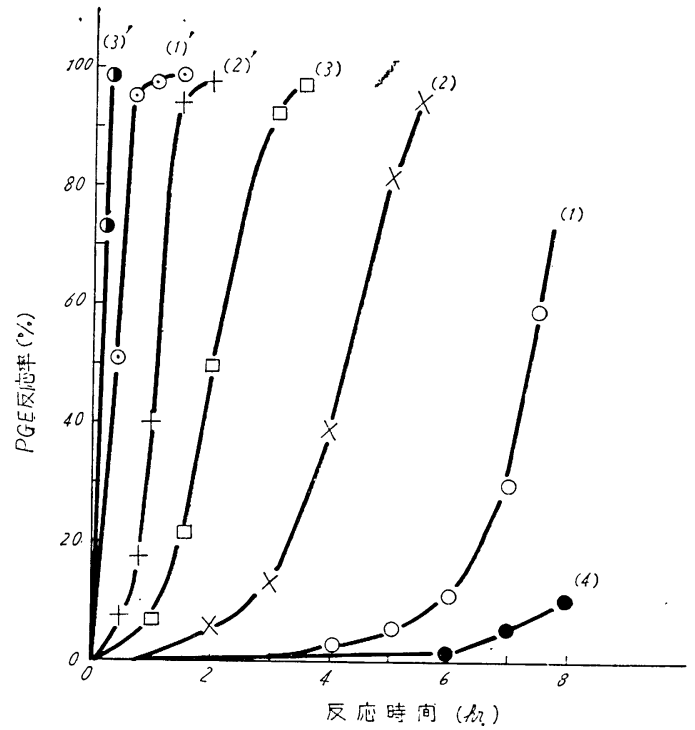

図 5 添加物の反応におよ添す影響

$\mathrm{PGE}: \mathrm{DM}:$ トリエチルアミン $=1: 1: 0.01 \mathrm{M}$ 比, $40 \pm 0.1 \mathrm{C}$ 测定

(1) ○添加物な几

(2) $\times$ エチルアルコール $\quad 0.03 \mathrm{~g}$ 添加

(3) $\square$ エチルアルコール $0.1 \mathrm{~g}$ 添加

(4) ・ ジラウリルスルファイド $0.36 \mathrm{~g}$ 添加

所定量のドデシルメルカプタンに金属ナトリウム $0.005 \mathrm{~g} を$

加え $\mathrm{C}_{12} \mathrm{H}_{25} \mathrm{SNa}$ の形で反応, アミン不在

$\mathrm{PGE}: \mathrm{DM}:=1: 1 \mathrm{M}$ 比の場合
$(1)^{\prime} \odot 50 \pm 0.1^{\circ} \mathrm{C}$
$(2)^{\prime}+40 \pm 0.1^{\circ} \mathrm{C}$
(3)' $40 \pm 0.1^{\circ} \mathrm{C}$ さららにエチルアルコール $0.3 \mathrm{~g}$ 添加

図 5 から，エチルアルコールの添加は反応を著しく促 進し，誘導期を短縮することがわかった。また，ジラウ リルスルフィドはかえって遅延させる結果となった。金 属ナトリウムの場合は触媒効果はトリエチルアミンなど よりさらに大であった。このときにもエチルアルコール の添加洨果があり，水酸基の促進効果が著しい。

6. PGE とラウリルアルコール（以下 LA と略記）

との反応アルコールとフェニルグリシジルエーテル との反応は疑一次式にしたがう ${ }^{14)}$ 。PGE と LA とを反 応させ反応率を求めた結果を 図 6 亿示した。

エポキシ基消失速度をつぎの一次式として計算した。

$$
\begin{aligned}
& k t=2.303 \log \frac{a}{a-x} \\
& \text { たた } \\
& (a-x): \mathrm{PGE} \text { 残存㵵度 }(\mathrm{M} / \mathrm{g})
\end{aligned}
$$

この結果を図 7 に示した。

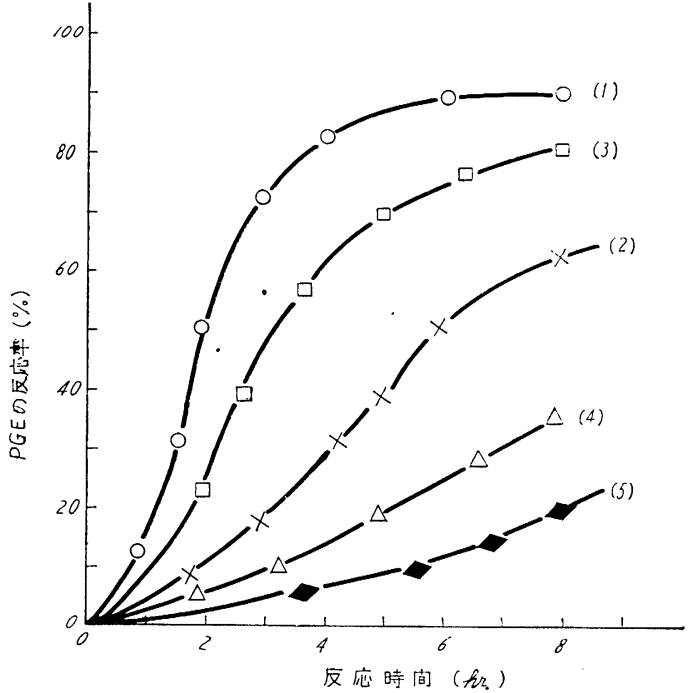

图 6 PGE と LA との反応 $(50 \pm 0.1 \mathrm{C}$ 测定 $)$ PGE : LA : $: ン$ M

(1) $\bigcirc 1: 1$ : トリエチルアミン $0.11(0.24 \mathrm{~g})$

(2) $\times 1: 1:$ : リエチルアミン $0.01(0.02 \mathrm{~g})$

(3) $\square 1$ : 1 : トリ-n-ブチルアミン $0.1(040 \mathrm{~g})$

(4) $\triangle 1: 1$ : トリ-n-ブチルアミン $0.01(0.04 \mathrm{~g})$

(5) $\downarrow 1: 0:$ : 1 リエチルアミン $0.1(0.22 \mathrm{~g})$ PGE 単独重合

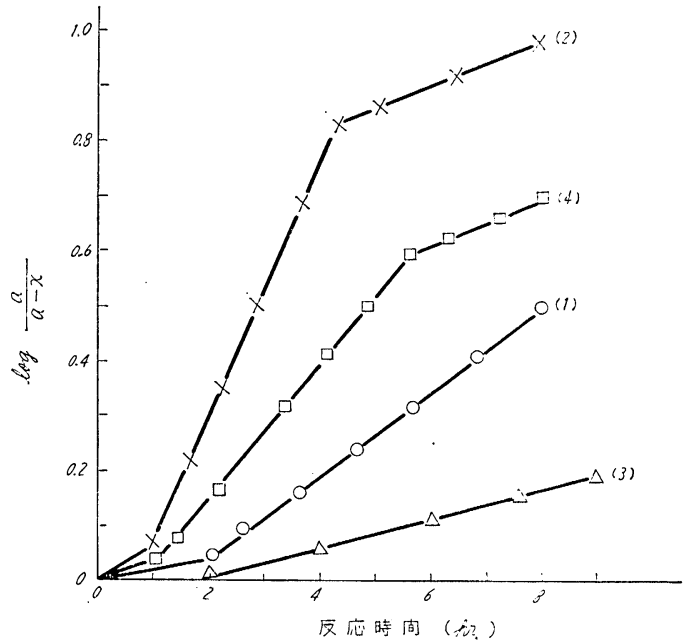

図 7 PGE と LA との反応速度 $\left(50 \pm 0.1^{\circ} \mathrm{C}\right.$ 测定 $)$ PGE : LA : アミン比M

(1) $\bigcirc 1: 1:$ : リエチルアミン 0.01

(2) $\times 1: 1:$ : 1 リエチルアミン 0.1

(3) $\triangle 1: 1:$ : リ-n-フチルアミン 0.01

(4) $\square 1: 1:$ : リ-nーブチルアミン 0.1

その結果，反応初期においては誘導期が認められ，触 媒量が多いと短縮されることがわかった。なお, 反応率 が 5〜75\% までは同一速度定数となるが，75\% 以上に なると速度定数が異なってくる。

7. PGE， LA， DM 三成分系での競争反応 $40 \pm$ $0.1{ }^{\circ} \mathrm{C}$ で行ない, $\mathrm{PGE}$ と生成物の水酸基と反応するか 
どうかを調べるために行なった試験である。その結果を

図 8 に示した。

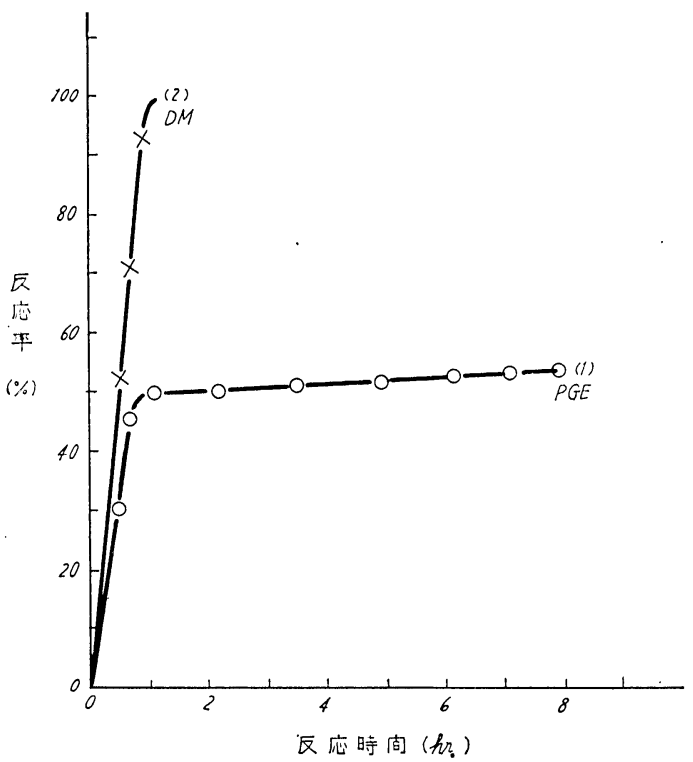

図 8 PGE の LA および DM との競争反応 $(40 \pm 0.1$ C $)$ PGE : LA : DM : トリエチルアミン = $2: 1: 1: 0.01 \mathrm{M}$ 比

(1) $\bigcirc$ PGE 反応率曲線

(2) $\times \mathrm{DM}$ 反応率曲線

図 8 から，反応開始後約 1 時間で全メルカプタンが反 応し，PGE の反応率は 50\% なのでこの反応は選択的 に行なわれ，アルコールの水酸基に接触されて速度が大 であったと考えられ，以後 PGE と LA とのゆるやかな 反応が行なわれるものと考えられる。アミンにより接触 される機構を考え、て見ると，

1) $\mathrm{R}_{3} \mathrm{~N}+\mathrm{R}^{\prime} \mathrm{SH} \longrightarrow \mathrm{R}_{3} \stackrel{\oplus}{\mathrm{N}} \mathrm{H}+\mathrm{R}^{\prime} \stackrel{\ominus}{\mathrm{S}}$

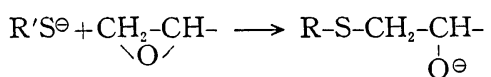

$\mathrm{R}^{\prime}-\mathrm{S}-\mathrm{CH}_{2}-\mathrm{CH}-+\mathrm{R}^{\prime} \mathrm{SH} \rightarrow \mathrm{R}^{\prime} \mathrm{S}-\mathrm{CH}_{2}-\mathrm{CH}-+\mathrm{R}^{\prime} \mathrm{S} \ominus$ $\mathrm{O} \Theta$ $\mathrm{OH}$

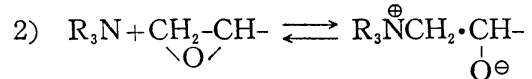

$$
\begin{aligned}
& \mathrm{R}_{3} \stackrel{\oplus}{\mathrm{N}} \mathrm{CH}_{2} \mathrm{CH}-+\mathrm{R}^{\prime} \mathrm{SH} \rightleftarrows \mathrm{R}_{3} \stackrel{\oplus}{\mathrm{N}} \mathrm{CH}_{2} \cdot \mathrm{CH}-+\mathrm{R}^{\prime} \mathrm{S} \Theta \\
& \text { Oे }
\end{aligned}
$$

の反応によりアニオンが生成し，これが反応触媒とな る。1),2)のどちらかの機構で反応が進むと考えられる。

8. 反応におよぼす添加物の影響の粘度法による 検 討 $\operatorname{PGE}(3 \mathrm{~m} l), \mathrm{DM}(5 \mathrm{ml})$, トリエチルアミン $(0.02 \mathrm{~g})$ 混合系に第 2 の添加物 $4.4 \times 10^{-4}$ モルを加え， $45 \pm 0.1^{\circ} \mathrm{C}$ で反応させ相対粘度変化（第 2 の添加物を加 えたときの落下時間/初めの落下時間）を求めた結果を 図 9,10に示した。

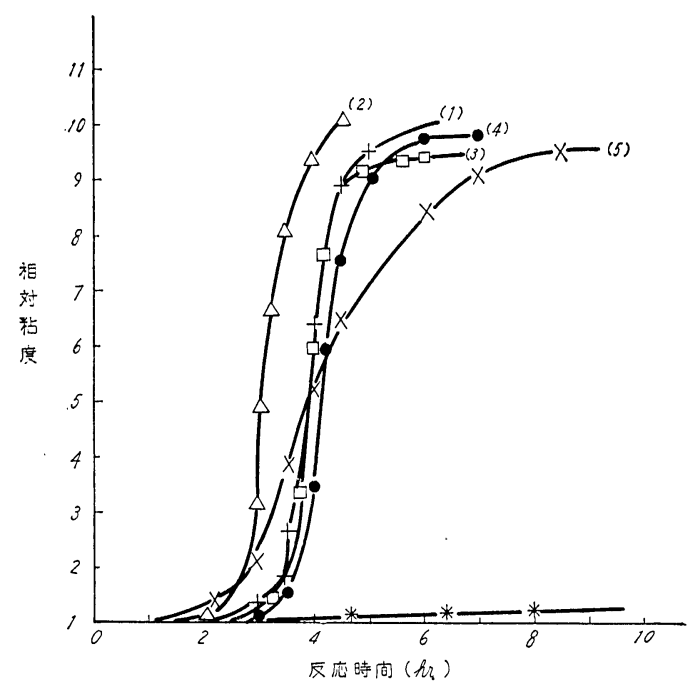

図 9 添加物を加えたときの粘度変化困

PGE : DM : トリエチルアミン =1: $1: 0.01 \mathrm{M}$ 比, $45 \pm 0.1$ C 测定

(1) + 添加物なし

(2) \エチルアルコール $0.02 \mathrm{~g}$ 添加

(3) $\square$ ニトロベンせン $0.06 \mathrm{~g} "$

(4) シメチルホルムアミト $0.036 \mathrm{~g} "$

(5) $\times$ フェノール $0.04 \mathrm{~g} "$

(6) * 酢 酸 $0.03 \mathrm{~g}$

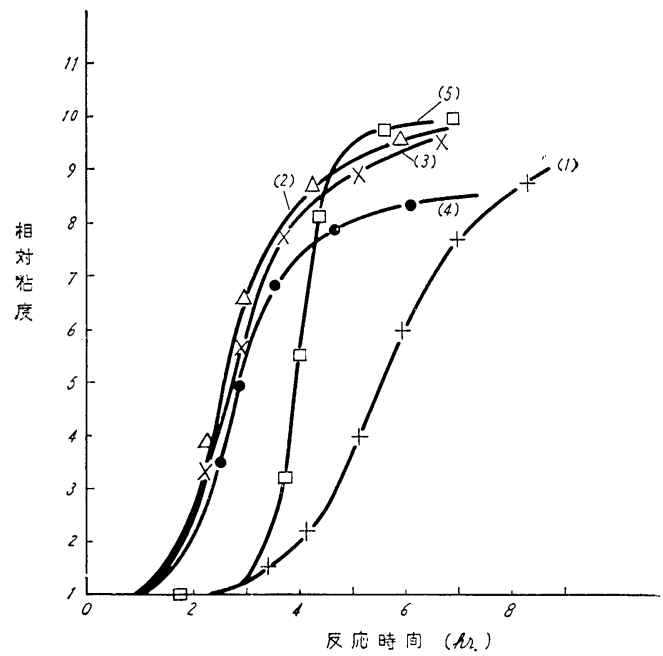

図 10 添加物を加えたときの粘度变化図 因 9 と同し M比と测定温度で实施
(1) + - -ナフトール $0.063 \mathrm{~g}$ 添加
(2) $\triangle$ o-キシレノール $0.054 \mathrm{~g} "$
(3) × pーメトキシフェノール $0.055 \mathrm{~g}$
(4) ○ $p$-ニトロフェノール $0.061 \mathrm{~g}$
(5) $\square$ 添加物なし

図 9,10 から, エチルアルコールの添加により反応進 行に伴ら粘度上昇が著しく, PGE 減少から求めた前の 結果によく対応している。したがって粘度法は反応速度 を知るための簡易法として採用できることがわかった。 
したがって前に実験しなかった添加物の定性的効果を図 9,10 から知ることができる。すなわちニトロベンゼン, ジメチルホルムアミドは影響なし，フェノール， $\alpha$-ナ フトールは少し抑制効果があり，フェノールに電子供給 基のメトキシルおよびメチル基のあるものは少し促進作 用があることがわかった。さらに酢酸の存在はほとんど 反応を進まなくさせることがわかった。これは触媒のト リエチルアミンが酢酸により遮へいされるためと考えら れる。

\section{IV. 結 論}

PGE とDM とのモデル実験によりメルカプタンはア ミンのアミド基のごとくエポキシ基との反忘性に富んで いるものではなく，硬化剤を添加し初めて著しく反応が 促進される。これらの硬化促進剤としてトリェチルアミ ン，トリーn-ブチルアミンのごとき第 $1,2,3$ 級ポリアミ ン，あるいはエチルアルコールなどが用いられる。約 $50^{\circ} \mathrm{C}$ の反応ではエポキシ基へのメルカプト基の付加反 応が主として起る。触媒無添加の場合, 反応にはかなり 高温 ( $150^{\circ} \mathrm{C}$ 以上) を要するが, 途中で反応が早くなる
現象は生成物自体の水酸基によって接触されること，ま た，アミン系触媒の種類により反応速度が異なるのは触 媒のアミンの塩基度と立体構造に原因すると推察される ことなどがわかった。

\section{文献}

1) K.R. Cranker, Ind. Eng. Chem. 4898 (1956)

2) L. Shechter, Ind. Eng. Chem. 48 94, 86 (1956); ibid. 491107 (1957)

3) 加倉井, 野口, 有合化 18485 (1960)

4) 同上, 工化 63294 (1960)

5) 酒井，杉山，石井，工化 67333 (1964)

6) 西村, 工化 652065 (1962)

7) $B P 730,670 ; 680,001 ; 681,991$

8) F. Berb'e, Bull. Soc. Chem. Belges 59449 (1956)

9）古川，小田，工化 55673 (1952)

10) Org. Synth. Coll. Vol. 1, 29, Vol. 2, 246

11) Org. Synth. Coll. Vol. 3, 363

12）杉山，有機化合物の微量確認法 p. 99 (培風館 干门)

13) Noller, J. Am. Chem. Soc. 682104 (1946)

14) C.G. Swain, J. Am. Chem. Soc. 70 1119(1948)

\section{日本学術会議第 8 期会員選挙登録について}

来年 11 月 25 日に日本学術会議第 8 期会員選挙が行 なわれます。日本学術会議会員の選挙において, 選挙 し，または選挙されるためには，日本学術会議事務局に 備えた有権者名簿に登録されなければなりません。

\section{1. 登録カードの提出について}

(1)前回（第 7 期昭和 40 年）の選挙の有権者について は, 前回提出のカードにより，本年資格審査が行な われました。これに関し, 日本学術会議中央選挙管 理会から登録カードを提出されるよら通知のあった 方以外の方は, すべて有権者名簿に登録されますか ら，あらためて登録用カードを提出する必要はあり ません。

(2)前回の選挙の有権者以外の方および前回の選挙の有 権者で中央選挙管理会からあらためて登録用カード を提出されるよう通知のあった方が，今回の選挙に 登録を求める場合は，中央選举管理会に登録用カー ド用紙を請求入手のうえ，昭和 43 年 3 月 31 日ま
でに中央選挙管理会に必着するよう登録用カードを 提出しなければなりません。

\section{2. 登録用カード用紙の請求について}

(1)登録用カード用紙の請求に関し, 大学, 研究機関等 に対して, 登録用カード用紙請求者名簿」の提出を 依頼して，便宜上これをもって「登録用カード用紙 請求書」に代え, その提出された名簿に基づき, 中 央選挙管理会から当該大学, 研究機関等あて一括力 ード用紙を送付します。

(2)前記大学, 研究機関等に所属しない方等で今後個人 でカード用紙を請求する方は「登録用カード用紙請 求書」を直接中央選挙管理会あて提出して下さい。

\section{3. 有権者等の異動届について}

有権者は氏名，住所，本籍，勤務機関および職名お よび勤務地のいずれかに異動があったとき，博士の 学位を取得した場合または住居表示の変更のあった ときは，そのつどすみやかに「有権者異動届」を中 央選挙管理会に提出しなければなりません。 